Original Research Paper

\title{
Evaluation of Antiviral Activity of Different Medicinal Plants against Newcastle Disease Virus
}

\author{
Khaldoun J. Al-Hadid \\ Department of Biological Sciences, Faculty of Science, \\ Hamdi Mango Research Center for Scientific Research, The University of Jordan, Amman, Jordan
}

\author{
Article history \\ Received: 28-05-2016 \\ Revised: $12-10-2016$ \\ Accepted: 27-10-2016
}

Email: kalhadid@ju.edu.jo

\begin{abstract}
Newcastle Disease (ND) is a highly contagious viral disease that has a tremendous negative impact on the poultry industry worldwide. Plant extracts were prepared from five different medicinal plants and applied against Newcastle Disease Virus (NDV) to evaluate the antiviral replication in Specific Pathogen-Free (SPF) chicken embryos. Three dilutions from each plant extract were prepared and mixed with a fixed titer $\left(10^{4} \mathrm{EID}_{50} / \mathrm{mL}\right)$ of virulent NDV strain Herts 33. The mix was inoculated into nine-day-old SPF chicken embryos that were monitored for five days. Real-time PCR and hemagglutination tests were conducted to evaluate the activity of NDV and its viral RNA titer. Some plant extracts showed a complete inhibition of NDV evidenced by the absence of embryo deaths, the absence of HA titer and viral RNA in the allantoic fluid. These plant extracts were from Moringa peregrina (leaves), Acacia cyanophylla (leaves), Eucalyptus camaldulensis (fruits) and Pistacia atlantica (leaves and stems). Other plant extracts showed partial inhibition of NDV, such as Ceratonia siliqua (leaves) and Eucalyptus camaldulensis (leaves). This experiment shows the potential of using medicinal plants as antiviral agents.
\end{abstract}

Keywords: Antiviral Activity, Medicinal Plants, Newcastle Disease Virus

\section{Introduction}

Newcastle Disease, caused by Newcastle Disease Virus (NDV), is a serious threat to the global poultry industry due to its high mortality rate. This is why outbreaks of virulent NDV require an immediate notification to the Office of International Epizootes (OIE) (Alexander, 2000). NDV is a negative-sense, singlestranded RNA virus of the family Paramyxoviridae. It is classified as an avian paramyxovirus 1 (APMV-1) (Taylor et al., 1990; De Leeuw and Peeters, 1999; Alexander, 2000). The NDV genome contains six major genes: Nucleocapsid, phosphoprotein, Matrix (M), Fusion (F), hemagglutinin-neuraminidase and RNA polymerase (De Leeuw and Peeters, 1999; Alexander, 2000). NDV isolates are classified into one of three pathotypes based on their pathogenicity: Lentogenic, mesogenic and velogenic (Alexander, 2000). This classification is confirmed by the presence of a cleavage site between amino acids 112-117 of NDV fusion protein. However, recent data suggest that this classification needs to be conducted not only by virus sequence analysis, but also by in vivo pathogenicity tests. These tests are required to demonstrate the clinical virulence of NDV as measured by the intracerebral pathogenicity index and the mean death time (Yu et al., 2001).

Vaccination is the main protector against NDV infection. However, different strategies are needed to either prevent the replication of NDV or to decrease its drastic effects on an infected flock (Dortmans et al., 2012; Miller et al., 2013). One of those strategies is investigating the antiviral activity of medicinal plant extracts against NDV infection (Waihenya et al., 2002). In fact, farmers mix medicinal plants with the poultry feed to increase the possibility of obtaining healthy chickens. In this study, I have selected five medicinal plants to test their antiviral activity against NDV. According to my knowledge, this is the first report of investigating the antiviral activity of NDV using plant materials of Moringa peregrina, Pistacia atlantica, Eucalyptus camaldulensis, Acacia cyanophylla and Ceratonia siliqua.

Moringa peregrina belongs to a flowering plant family called Moringaceae. This family has only one genus, called Moringa, which contains fourteen species 
from different tropical and subtropical regions (Dehshahri et al., 2012; Al Khateeb et al., 2013). Species of this family are distributed from the Dead Sea to southern Arabia and northern Somalia (Carvalho and Renner, 2012). Moringa peregrina is a good source of proteins, vitamins $\mathrm{A}, \mathrm{C}$ and $\mathrm{B}$, minerals and calcium. This is why leaves and pods are used as livestock feed (Asghari et al., 2015). The active biological ingredients of Moringa peregrina show anti-hyperglycemic and cytotoxic activity (El-Alfy et al., 2011).

Pistacia atlantica is a deciduous plant that belongs to Anacardiaceae family, which comprises about 600 species (Bozorgi et al., 2013). This plant is widely distributed worldwide, particularly in the Mediterranean region (Bozorgi et al., 2013). In folk medicine, Pistacia atlantica is used in the treatment of several diseases, such as; hypertension, eczema, kidney stones, cough and asthma (Tohidi et al., 2011; Oran and Al-Eisawi, 2015). In fact, Pistacia species demonstrates antioxidant, antimicrobial, anti-inflammatory, anti-diarrheal, antiulcer and hypoglycemic activity (Benhammou et al., 2007; 2008). Pistacia is rich in triterpenoids, phenolic compounds, fatty acids and sterols (Bozorgi et al., 2013). Recently, it was shown that essential oil of Pistacia atlantica has many different compounds, such as myrcene, limonene and sabinene (Bozorgi et al., 2013).

Eucalyptus camaldulensis is an evergreen tree that grows in a wide range of climatic conditions ranging from high rainfall to extreme drought. The essential oil of Eucalyptus camaldulensis leaves contains bioactive compounds that have antibacterial, anti-inflammatory, insecticidal, antioxidative and antiradical activity (Cheng et al., 2009; Silva et al., 2010; Huang et al., 2015). In folk medicine, Eucalyptus is used to combat upper respiratory tract infections and as an antiseptic drug (Silva et al., 2003).

Acacia cyanophylla evergreen plant belongs to Fabaceae family. The Acacia genus contains more than 1,030 species that are distributed in the sub-arid and arid portions of the world (Nasri et al., 2013). Acacia cyanophylla has antimicrobial (Ayeb-Zakhama et al., 2015), hypoglycemic (Wadood et al., 1989) and antiinflammatory activity (Al-Mustafa and Dafallah, 2000). It has high level of tannins, phenolic compounds, carotenoids, tocopherols and sterols (Ben Salem et al., 1997; Nasri et al., 2013).

Ceratonia siliqua is an evergreen tree that belongs to Fabaceae family. This tree is characterized as slow-growing and adapted to drought conditions (Oliveira et al., 2011). The production of Ceratonia pods is estimated to be more than 300 tons per year, from about 200,000 hectares planted worldwide (Makris and Kefalas, 2004). In folk medicine, the plant is used to treat infant diarrhea (Loeb et al., 1989), cough and as an anti-diuretic agent (Oran and Al-Eisawi, 2015). The leaves and pulp have antimicrobial (Kivack et al., 2002), antioxidant (Papagiannopoulos et al., 2004) and anti-proliferative activity (Corsi et al., 2002). In fact, Ceratonia silique pod is rich in sugars, tannins, dietary fiber and polyphenols (Papagiannopoulos et al., 2004).

Using herbal extracts along with the NDV vaccine can enhance both cell-mediated (proliferation assay) and humoral immunity (increase in the anti-NDV antibodies titer) (Kong et al., 2004; 2006). Therefore, in this study, the use of some medicinal plants as antiNDV was investigated.

\section{Materials and Methods}

\section{Preparation of Plant Extracts and Newcastle Disease Virus}

Five medicinal plants were collected and air-dried at room temperature. Different plant parts were used: The leaves of Moringa peregrina, the stem and the leaves of Pistacia atlantica, the fruits and the leaves of Eucalyptus camaldulensis, the leaves of Acacia cyanophylla and the leaves of Ceratonia siliqua.

Plant materials were ground to a fine powder. Plant ethanol extracts were prepared by adding absolute ethanol to plant material $1: 2(\mathrm{w} / \mathrm{v})$. The suspension was incubated for $72 \mathrm{~h}$ at room temperature with gentle shaking. The plant suspension was filtered using Whatman paper (No. 1). The filtrate was concentrated using a rotary evaporator to remove the ethanol. The plant extract was suspended by adding $5.0 \mathrm{~mL}$ dimethyl sulfoxide (DMSO) to $0.5 \mathrm{~g}$ plant extract. Three concentrations of plant extracts were prepared: 500, 250 and $50 \mu \mathrm{g} \mathrm{mL}^{-1}$. These dilutions were mixed with Herts 33 strain of NDV in a titer of $10^{4} \mathrm{EID}_{50} / \mathrm{mL}$ and used in the in ovo experiment. $100 \%$ DMSO (Sigma. USA) was used to prepare all concentrations. DMSO has no effect on NDV activity (Bakari et al., 2012).

\section{In ovo anti-Newcastle Disease Virus Experiment}

Nine-day-old SPF chicken embryos were bought from a local hatchery. Three dilutions of each plant crude extract $\left(500,250\right.$ and $\left.50 \mu \mathrm{g} \mathrm{mL}^{-1}\right)$ were mixed $1: 9$ with virulent NDV Herts 33 strain $\left(10^{4} \mathrm{EID}_{50} / \mathrm{mL}\right)$ and maintained at room temperature for one hour. After incubation, $100 \mu \mathrm{L}$ of the plant-virus mixture was inoculated into the allantoic cavity. $100 \%$ DMSO was used to prepare all the dilutions. The final DMSO concentration used in vivo was $10 \%$.

SPF eggs were incubated and monitored for five days. Embryo mortality was recorded daily. The allantoic fluid was harvested from dead and living embryos and then stored at $-80^{\circ} \mathrm{C}$. The positive control used for this experiment was NDV Herts 33 strain and the negative control was 1x Phosphate-Buffered Saline (PBS).

\section{Hemagglutination (HA) Titration for Newcastle Disease Virus}

A standard hemagglutination test was conducted on the harvested allantoic fluid to calculate NDV HA 
titer for each sample. $25 \mu \mathrm{L}$ of PBS was added into each well of a V-96 well plate. The same volume of inactive NDV was added to the first well. A two-fold dilution of $25 \mu \mathrm{L}$ of the virus was prepared for each well of the whole plate. $25 \mu \mathrm{L}$ of $1 \%(\mathrm{v} / \mathrm{v})$ chicken RBCs was added to each well. Then, the solution was mixed gently in each well. The plate was incubated for $40 \mathrm{~min}$ at room temperature. Negative NDV chicken serum and positive NDV chicken serum were used as controls.

\section{Viral RNA Isolation and Quantitative Real-time PCR Analysis}

Allantoic fluids from dead and living SPF eggs were collected for viral RNA extraction to conduct a Realtime PCR experiment. Total RNA was extracted using the QIAamp Viral RNA Mini Kit (Qiagen, Germany), according to the kit manufacturer's instructions. RNA was evaluated quantitatively and qualitatively using a spectrophotometer. The QuantiFast Probe RT kit was used (Qiagen, Germany) for the real-time PCR experiment. Primers and probe sequences for NDV detection were constructed according to (Farkas et al., 2009). The sequences are: NDVNP-F: TCTCTTATGCTCCCACTCTCAAGT, NDVNP: R CGATCTCAAGAACAGCCAGTGT, probe: CCTTGCAGGGAAACAG. Real-time PCR reaction volumes and conditions were applied as mentioned in (Farkas et al., 2009). Proper controls were included in each run. Results of the real-time PCR were expressed as a threshold cycle $(\mathrm{Ct})$. A low $\mathrm{Ct}$ value indicates high viral RNA concentration, whereas a high $\mathrm{Ct}$ value indicates low viral RNA concentration in the sample.

\section{Results}

The mortality of the SPF embryos was recorded for five days post-inoculation with the plant-virus mixture (Table 1). Some plant extracts showed complete inhibition of NDV. For instance, high and medium concentrations (500 and $250 \mu \mathrm{g} \mathrm{mL} \mathrm{mL}^{-1}$ ) of Moringa peregrina leaves extract had a complete inhibition of the NDV replication with zero mortality. However, when low concentration $\left(50 \mu \mathrm{g} \mathrm{mL}^{-1}\right)$ of Moringa peregrina leaves extract was used, the mortality was $40 \%$. Similar results were obtained using Eucalyptus camaldulensis fruits, which showed complete NDV inhibition at low and medium plant extract concentrations. However, $20 \%$ mortality was recorded when a high Eucalyptus camaldulensis fruits extract concentration (500 $\mu \mathrm{g} \mathrm{mL}^{-1}$ ) was used. Ceratonia siliqua leaves extract did not show complete NDV inhibition at any of the plant extract concentrations. High, medium and low Ceratonia siliqua leaves extract concentrations $\left(500,250\right.$ and $50 \mu \mathrm{g} \mathrm{mL}^{-1}$ ) showed 20 , 40 and $80 \%$ mortality, respectively. This demonstrates a dose-dependent pattern of plant extract and mortality.

An optimal concentration of plant extract was able to inhibit the replication of NDV inside the embryonated SPF eggs. For instance, medium concentration $(250 \mu \mathrm{g}$ $\mathrm{mL}^{-1}$ ) of Pistacia atlantica (leaves and stem), Eucalyptus camaldulensis fruits and Acacia cyanophylla leaves extracts showed zero mortality.

To investigate the activity of NDV in the collected allantoic fluids, the HA titer was calculated. HA titer was not detectable for plant extract treatments with complete NDV inhibition and zero mortality. However, the mean NDV HA titer ranged from 3.0 to 5.6 for plant extracts of 20 to $80 \%$ mortality (Table 2). Moreover, the threshold cycle $(\mathrm{Ct})$ value was not detected for the plant extracts that yielded zero mortality. This indicates the absence of NDV viral RNA in SPF eggs. However, Ct values ranged from 27.5 to 34.1 for the plant extracts that yielded some mortality. This indicates the presence of NDV viral RNA in SPF eggs. Real-time PCR results match well with the NDV HA titer results (Table 2). A correlation coefficient $\left(R^{2}\right)$ value was calculated as 0.99 for the real-time PCR experiment (Fig. 1).

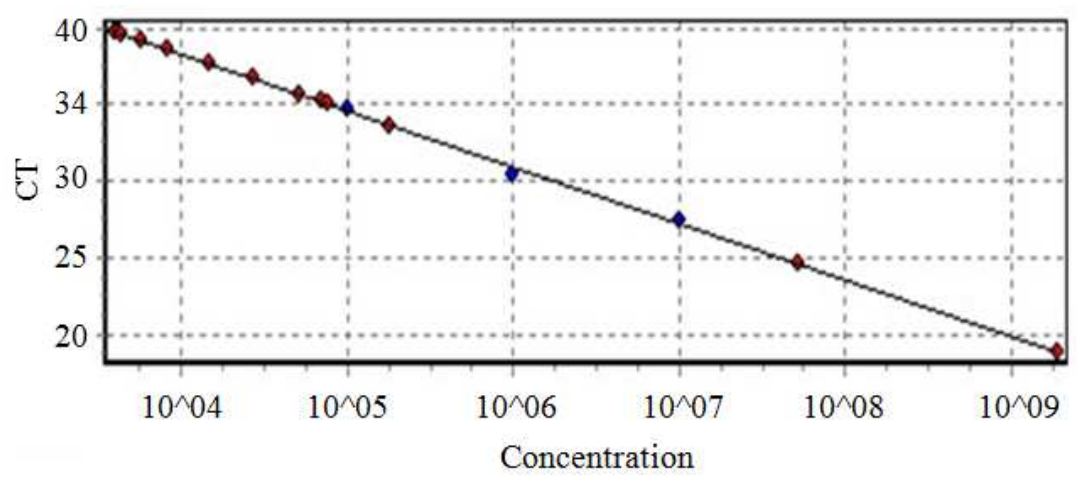

Fig. 1. Real-time PCR correlation coefficient $\left(\mathrm{R}^{2}\right)$. $\mathrm{R}^{2}$ value was 0.99065 for the quantification of the viral RNA titer of NDV. This shows that the real-time experiment was conducted with a high degree of accuracy 
Table 1. Mortality percentage of in ovo anti-Newcastle disease experiment for different plant extract treatments

\begin{tabular}{|c|c|c|c|c|c|c|c|}
\hline \multirow{2}{*}{$\begin{array}{l}\text { Plant part } \\
\text { Plant extract } \\
\text { concentration }^{\mathrm{a}}\end{array}$} & \multicolumn{5}{|l|}{ Leaves } & \multirow[b]{2}{*}{$\begin{array}{l}\text { Fruits } \\
\text { E. camaldulensis }\end{array}$} & \multirow[b]{2}{*}{$\begin{array}{l}\text { Stem } \\
\text { P. atlantica }\end{array}$} \\
\hline & M. peregrina & P. atlantica & E. camaldulensis & A. cyanophylla & C. siliqua & & \\
\hline$\overline{500 \mu \mathrm{g} \mathrm{mL}}{ }^{-1}$ & $0 / 5: 0 \% *$ & $1 / 5: 20 \%$ & $3 / 5: 60 \%$ & $2 / 5: 40 \%$ & $1 / 5: 20 \%$ & $1 / 5: 20 \%$ & $1 / 5: 20 \%$ \\
\hline $250 \mu \mathrm{g} \mathrm{mL}^{-1}$ & $0 / 5: 0 \%$ & $0 / 5: 0 \%$ & $2 / 5: 40 \%$ & 0/5:0\% & $2 / 5: 40 \%$ & $0 / 5: 0 \%$ & 0/5:0\% \\
\hline $50 \mu \mathrm{g} \mathrm{mL}^{-1}$ & $2 / 5: 40 \%$ & $1 / 5: 20 \%$ & $2 / 5: 40 \%$ & $1 / 5: 20 \%$ & $4 / 5: 80 \%$ & $0 / 5: 0 \%$ & $3 / 5: 60 \%$ \\
\hline
\end{tabular}

* Mortality Percentage (0/5: zero\%, 5/5: 100\%)

Table 2. Calculated mean HA titer and threshold cycle $(\mathrm{Ct})$ for the different plant extract treatments. HA titer mean is inversely proportional to the amount of viral RNA

\begin{tabular}{|c|c|c|c|c|c|c|c|c|c|c|c|c|c|c|c|c|c|c|c|c|}
\hline \multirow{2}{*}{$\begin{array}{l}\text { Plant part } \\
\text { Plant extract }\end{array}$} & \multicolumn{13}{|c|}{ Leaves } & \multicolumn{3}{|c|}{ Fruits } & \multicolumn{4}{|c|}{ Stem } \\
\hline & \multicolumn{2}{|c|}{ M. peregrina } & \multicolumn{3}{|c|}{ P. atlantica } & \multicolumn{3}{|c|}{ E. camaldulensis } & \multicolumn{3}{|c|}{ A. cyanophylla } & \multicolumn{2}{|c|}{ C. siliqua } & \multicolumn{3}{|c|}{ E. camaldulensis } & \multicolumn{4}{|c|}{ P. atlantica } \\
\hline concentration $^{\mathrm{a}}$ & 500 & $250 \quad 50$ & 500 & 250 & 50 & 500 & 250 & 50 & 500 & 250 & 50 & 500 & 250 & 50 & 500 & 250 & 50 & 500 & 250 & 50 \\
\hline $\begin{array}{l}\text { HA titer } \\
\left(\text { Mean Log }{ }^{2}\right) \\
\text { Viral RNA }\end{array}$ & $\mathrm{ND}^{\mathrm{c}}$ & ND 5.3 & 3 & ND & 4 & 5 & 5 & 4.3 & 3 & ND & 3 & 3.6 & 4.3 & 5.6 & 3.3 & ND & ND & 3.3 & ND & 5.6 \\
\hline titer in $\mathrm{Ct}^{\mathrm{b}}$ & ND & ND 29.4 & 31.4 & ND & 31.9 & 28.6 & 31.6 & 30 & 32.4 & 34.1 & 32.3 & 31.7 & 33 & 27.5 & 29.4 & ND & ND & 33 & ND & 29 \\
\hline
\end{tabular}

\section{Discussion}

Newcastle Disease Virus remains a continuous threat to the poultry industry worldwide due to the capability of the virulent strains to cause high mortality. Vaccination against NDV has a crucial role in protecting poultry from the virulent strains of NDV (Miller et al., 2013). However, the vaccine could take a long time to initiate the protective immune system. Therefore, different strategies to either prevent the replication of NDV or to decrease its drastic impact on infected flocks are needed (Park et al., 2014). One of those potential strategies is to use medicinal plant extracts as antiviral agents against NDV either in cell culture or chicken embryo systems (Waihenya et al., 2002). Therefore, in this study, we examined the antiviral activity of five medicinal plants on the inhibition of NDV replication inside SPFembryonated eggs. These plants were: Moringa peregrina, Pistacia atlantica, Eucalyptus camaldulensis, Acacia cyanophylla and Ceratonia silique. These plants were selected due to their potential as antiviral agents since their antimicrobial activities have been reported (Cimanga et al., 2002; Kivack et al., 2002; Ayeb-Zakhama et al., 2015; Roozegar et al., 2016). Moreover, these plants are distributed worldwide. This makes them available to farmers with low cost. The most dominant part of these plants are the leaves. This is why leaves were selected for this study. However, the essential oil of E. camaldulensis fruits was reported to have an antimicrobial activity (Knezevic et al., 2016). Therefore, E. camaldulensis fruits were selected for this study. $P$. atlantica stem was selected to find out if the stem has a different effect than the leaves.

Responses to the different treatments using medicinal plant extracts to protect chicken embryos against NDV can be classified into four groups. Group I is represented by Moringa peregrina leaves and Eucalyptus camaldulensis fruits, where some concentrations of plant extracts showed complete inhibition of the virus with zero mortality. The Moringa peregrina leaves extract required moderate to high concentrations to achieve complete inhibition and zero mortality. However, the Eucalyptus camaldulensis fruits extract showed complete inhibition of the virus and zero mortality at low and moderate plant material concentrations. When the Eucalyptus camaldulensis fruits extract was applied at high concentration, a $20 \%$ mortality was measured. This could be due to reaching some level of toxicity to the chicken embryo.

Group II is represented by Pistacia atlantica (stem and leaves) and Acacia cyanophylla leaves, where a medium plant extract concentration was able to provide complete inhibition of the virus, whereas low and high concentrations of the plant extract showed some percentage of mortality. This means that low plant extract concentrations were not enough to provide complete protection from the virus, while high plant extract concentrations were toxic to the chicken embryo. Stem and leaves had similar effect. This could indicate that the active ingredient that is responsible of the viral inhibition and the toxicity exists into both parts.

Group III is represented by Ceratonia siliqua leaves, where a dependent-dose plant extract response is observed as the degree of virus inhibition. However, complete inhibition of viral activity was not obtained, suggesting the need to apply higher concentrations of the plant extract.

Group IV is represented by Eucalyptus camaldulensis leaves, where no complete inhibition of the viral activity was detected using any concentration of the plant material. However, at higher concentrations 
of the extract, the same or higher mortality was measured. This is due to increasing toxicity when using higher concentrations of plant material. The virus did not affect the mortality since similar RNA viral amounts were detected.

These results correlate almost perfectly in most of the treatments with the detected viral RNA in each sample using real-time PCR technique. Plant extract concentrations yielding complete inhibition of the viral activity had no NDV viral RNA. However, plant extract concentrations with partial inhibition of the viral activity had low NDV viral RNA. Here, I showed that some of these medicinal plant extracts were able to provide complete protection for the SPF embryos against NDV with zero mortality.

Farmers are recommended to use plant extracts as one of the protective practices to inhibit NDV. The recommended doses are $250 \mu \mathrm{g} \mathrm{mL}^{-1}$ of Moringa peregrina leaves, $250 \mu \mathrm{g} \mathrm{mL} \mathrm{m}^{-1}$ of Pistacia atlantica leaves or stem and $50 \mu \mathrm{g} \mathrm{mL} \mathrm{m}^{-1}$ of Eucalyptus camaldulensis fruit. The results of this study confirm those of other studies that used medicinal plant extracts as antiviral agents against NDV. For instance, the inhibitory concentration of Adansonia digitata bark or Psidium guajava leaves was 200-250 $\mathrm{mg} \mathrm{mL}^{-1}$ against NDV (Sulaiman et al., 2011; Chollom et al., 2012a). Moreover, the inhibitory concentrations of fruit pulp and leaves of Momordica balsamina was $10-20 \mathrm{mg} \mathrm{mL}^{-1}$ (Chollom et al., 2012b). Other medicinal plants showed stronger inhibitory effects, such as leaves, roots and stem bark of Commiphora swynnertonii, which had an inhibitory concentration of $500 \mu \mathrm{g} \mathrm{mL}{ }^{-1}$ against NDV (Bakari et al., 2013). Therefore, Moringa peregrina leaves extract and Pistacia atlantica leaves and stem extracts have strong inhibitory effects against NDV, while Eucalyptus camaldulensis fruit extract has a very strong inhibitory effect against NDV.

Further experiments need to be conducted to test the use of those plant extracts that showed complete inhibition of the viral activity and zero mortality as supplements to broilers' diets to protect them against NDV. Moreover, further studies will include the precise dose to be used for inhibition within the range of plant extract concentrations that were tested in this study.

\section{Conclusion}

Ethanolic extracts of Moringa peregrina leaves, Acacia cyanophylla leaves, Eucalyptus camaldulensis fruits and Pistacia atlantica (leaves and stem) showed complete inhibition of NDV without causing death of the chicken embryo. The response of the viral-infected chicken embryos is different depending on the species of the medicinal plant, plant part and the plant material concentration applied. Some plant extracts show a dosedependent relationship with the degree of the virus inhibition, whereas other plant extracts showed some toxicity on the chicken embryo. This study shows the potential of using medicinal plant extracts as an antiviral agent to protect broilers from NDV.

\section{Acknowledgement}

I would like to thank Royal Botanic Garden of Jordan and the National Center for Agricultural Research and Extension for providing the plant materials. I also would like to acknowledge Dr. Mustafa Ababneh for facilitating the molecular work in his lab at Jordan University of Science and Technology, Irbid, Jordan.

\section{Funding Information}

I would like to thank Hamdi Mango Research Center for Scientific Research, The University of Jordan, Amman, Jordan, for providing the fund for this project.

\section{References}

Al Khateeb, W., E. Bahar, J. Lahham, D. Schroeder and E. Hussein. 2013. Regeneration and assessment of genetic fidelity of the endangered tree Moringa peregrina (Forsk.) Fiori using Inter Simple Sequence Repeat (ISSR). Physiol. Molecular Biol. Plants, 19: 157-164. DOI: $10.1007 / \mathrm{s} 12298-012-0149-\mathrm{z}$

Alexander, D., 2000. Newcastle disease and other avian paramyxovirus. Rev. Sci. Tech. Off. Int. Epiz., 19: 443-462. DOI: 10.20506/rst.19.2.1231

Al-Mustafa, Z.H. and A.A. Dafallah, 2000. A study on the toxicology of Acacia nilotica. Am. J. Chinese Med., 28: 123-129. DOI: $10.1142 / \mathrm{S} 0192415 \mathrm{X} 00000155$

Asghari, G., A. Palizban and B. Bakhshaei, 2015. Quantitative analysis of the nutritional components in leaves and seeds of the Persian Moringa peregrina (Forssk.) Fiori. Pharmacognosy Res., 7: 242-248. DOI: $10.4103 / 0974-8490.157968$

Ayeb-Zakhama, E., L. Sakka-Rouis, A. Bergaoui, G. Flamini and H. Ben Jannet et al., 2015. Chemical composition and allelopathic potential of essential oils obtained from Acacia cyanophylla LINDL. Chem. Biodiversity, 12: 615-626. DOI: $10.1002 / \mathrm{cbdv} .201400184$

Bakari, G.G., R.A. Max, R.H. Mdegela, E.C. Phiri and M.M. Mtambo, 2012. Antiviral activity of crude extracts from Commiphora swynnertonii against Newcastle disease virus in ovo. Tropical Anim. Health Produc., 44: 1389-1393. DOI: $10.1007 / \mathrm{s} 11250-012-0076-6$

Bakari, G., R. Max, H. Mdegela, E. Phiri and M. Mtambo, 2013. Effect of resinous extract from Commiphora swynnertonii (Burrt) on experimental coccidial infection in chickens. Int. J. Med. Plants Res., 2: 156-161. DOI: 10.1007/s11250-012-0239-5 
Ben Salem, H., A. Nefzaoui, L. Ben Salem and J. Tisserand, 1997. Effect of Acacia cyanophylla Lindl. foliage supply on intake and digestion by sheep fed lucerne hay-based diets. Anim. Feed Sci. Technol., 68: 101-113. DOI: 10.1016/S0377-8401(97)00015-1

Benhammou, N., F.A. Bekkara and T.K. Panovska, 2007. Antiradical capacity of the phenolic compounds of Pistacia lentiscus L. and Pistacia atlantica Desf. Adv. Food Sci., 29: 155-161.

Benhammou, N., F.A. Bekkara and T.K. Panovska, 2008. Antioxidant and antimicrobial activities of the Pistacia lentiscus and Pistacia atlantica extracts. Afr. J. Pharmacy Pharmacol., 2: 022-028.

Bozorgi, M., Z. Memariani, M. Mobli, M.H. Salehi Surmaghi and M.R. Shams-Ardekani et al., 2013. Five Pistacia species (P. vera, $P$. atlantica, $P$. terebinthus, $P$. khinjuk and $P$. lentiscus): A review of their traditional uses, phytochemistry and pharmacology. Sci. World J. DOI: 10.1155/2013/219815

Carvalho, F.A. and S.S. Renner, 2012. A dated phylogeny of the papaya family (Caricaceae) reveals the crop's closest relatives and the family's biogeographic history. Mol. Phylogenet. Evolu., 65: 46-53. DOI: 10.1016/j.ympev.2012.05.019

Cheng, S.S., C.G. Huang, Y.J. Chen, J.J. Yu and W.J. Chen et al., 2009. Chemical compositions and larvicidal activities of leaf essential oils from two eucalyptus species. Bioresour. Technol., 100: 452-456. DOI: 10.1016/j.biortech.2008.02.038

Chollom, S., A. Olawuyi, L. Danjuma, L. Nanbol and I. Makinde et al., 2012a. Antiviral potential of aqueous extracts of some parts of Momordica balsamina plant against newcastle disease virus. J. Adv. Pharmacy Educ. Res., 2: 82-92.

Chollom, S., G. Agada, D. Bot, M. Okolo and D. Dantong et al., 2012b. Phytochemical analysis and antiviral potential of aqueous leaf extract of Psidium guajava against newcastle disease virus in ovo. J. Applied Pharmaceut. Sci., 2: 45-49. DOI: $10.7324 /$ JAPS.2012.21009

Cimanga, K., K. Kambu, L. Tona, S. Apers and T. De Bruyne et al., 2002. Correlation between chemical composition and antibacterial activity of essential oils of some aromatic medicinal plants growing in the democratic republic of Congo. J. Ethnopharmacol., 79: 213-220. DOI: $10.1016 / \mathrm{s} 0378-8741(01) 00384-1$

Corsi, L., R. Avallone, F. Cosenza, F. Farina and C. Baraldi et al., 2002. Antiproliferative effects of Ceratonia siliqua L. on mouse hepatocellular carcinoma cell line. Fitoterapia, 73: 674-684.

DOI: $10.1016 / \mathrm{S} 0367-326 \mathrm{X}(02) 00227-7$

De Leeuw, O. and B. Peeters, 1999. Complete nucleotide sequence of Newcastle disease virus: Evidence for the existence of a new genus within the subfamily Paramyxovirinae. J. General Virol., 80: 131-136. DOI: 10.1099/0022-1317-80-1-131
Dehshahri, S., M. Wink, S. Afsharypuor, G. Asghari and A. Mohagheghzadeh, 2012. Antioxidant activity of methanolic leaf extract of Moringa peregrina (Forssk.) Fiori. Res. Pharm. Sci., 7: 111-118. PMID: 23181088

Dortmans, J.C., B.P. Peeters and G. Koch, 2012. Newcastle disease virus outbreaks: Vaccine mismatch or inadequate application? Vet. Microbiol., 160: 17-22. DOI: 10.1016/j.vetmic.2012.05.003

El-Alfy, T.S., S.M. Ezzat, A.K. Hegazy, A.M. Amer and G.M. Kamel, 2011. Isolation of biologically active constituents from Moringa peregrina (Forssk.) Fiori. (family: Moringaceae) growing in Egypt. Pharmacogn. Mag., 7: 109-115. DOI: 10.4103/0973-1296.80667

Farkas, T., E. Szekely, S. Belak and I. Kiss, 2009. Realtime PCR-based pathotyping of Newcastle disease virus by use of TaqMan minor groove binder probes. J. Clin. Microbiol., 47: 2114-2123. DOI: $10.1128 / \mathrm{JCM} .01652-08$

Huang, H.C., Y.C. Ho, J.M. Lim, T.Y. Chang and C.L. Ho et al., 2015. Investigation of the antimelanogenic and antioxidant characteristics of Eucalyptus camaldulensis flower essential oil and determination of its chemical composition. Int. J. Mol. Sci., 16: 10470-10490. DOI: 10.3390/ijms 160510470

Kivack, B., T. Mert and H. Tansel, 2002. Antimicrobial and cytotoxic activities of Ceratonia siliqua L. extracts. Turkish J. Biol., 26: 197-200.

Knezevic, P., V. Aleksic, N. Simin, E. Svircev and A. Petrovic et al., 2016. Antimicrobial activity of Eucalyptus camaldulensis essential oils and their interactions with conventional antimicrobial agents against multi-drug resistant Acinetobacter baumannii. J. Ethnopharmacol., 178: 125-136. DOI: $10.1016 /$ j.jep.2015.12.008

Kong, X.F., Y.L. Hu, Y.L. Yin, G.Y. Wu and R. Rui et al., 2006. Chinese herbal ingredients are effective immune stimulators for chickens infected with the Newcastle disease virus. Poult. Sci., 85: 2169-2175. DOI: $10.1093 / \mathrm{ps} / 85.12 .2169$

Kong, X., Y. Hu, R. Rui, D. Wang and X. Li, 2004. Effects of Chinese herbal medicinal ingredients on peripheral lymphocyte proliferation and serum antibody titer after vaccination in chicken. Int. Immunopharmacol., 4: 975-982. DOI: 10.1016/j.intimp.2004.03.008

Loeb, H., Y. Vandenplas, P. Würsch and P. Guesry, 1989. Tannin-rich carob pod for the treatment of acute-onset diarrhea. J. Pediatric Gastroenterol. Nutrit., 8: 480-485. DOI: $10.1097 / 00005176-198905000-00010$

Makris, D. P. and P. Kefalas, 2004. Carob Pods (Ceratonia siliqua L.) as a Source of Polyphenolic Antioxidants. Food Technol. Biotechnol., 42: 105-108.

Miller, P.J., C.L. Afonso, J. El Attrache, K.M. Dorsey and S.C. Courtney et al., 2013. Effects of Newcastle disease virus vaccine antibodies on the shedding and transmission of challenge viruses. Develop. Compar. Immunol., 41: 505-513. DOI: 10.1016/j.dci.2013.06.007 
Nasri, N., W. Elfalleh, N. Tlili, L. Martine and O. Berdeaux et al., 2013. Contents of carotenoids, tocopherols and sterols in Acacia cyanophylla seed oils. J. Am. Oil Chem. Society, 90: 429-436.

DOI: $10.1007 / \mathrm{s} 11746-012-2181-0$

Oliveira, G., A. Nunes, A. Clemente and O. Correia, 2011. Effect of substrate treatments on survival and growth of Mediterranean shrubs in a revegetated quarry: An eight-year study. Ecol. Eng., 37: 255-259. DOI: $10.1016 /$ j.ecoleng.2010.11.015

Oran, S.A. and D.M. Al-Eisawi, 2015. Ethnobotanical survey of the medicinal plants in the central mountains (North-South) in Jordan. J. Biodiversity Environ. Sci., 6: 381-400.

Papagiannopoulos, M., H.R. Wollseifen, A. Mellenthin, B. Haber and R. Galensa, 2004. Identification and quantification of polyphenols in carob fruits (Ceratonia siliqua L.) and derived products by HPLC-UV-ESI/MS ${ }^{\mathrm{n}}$. J. Agric. Food Chem., 52: 3784-3791. DOI: 10.1021/jf030660y

Park, J.K., D.H. Lee, S.S. Yuk, E.O. Tseren-Ochir and J.H. Kwon et al., 2014. Virus-like particle vaccine confers protection against a lethal newcastle disease virus challenge in chickens and allows a strategy of differentiating infected from vaccinated animals. Clin. Vaccine Immunol., 21: 360-365.

DOI: $10.1128 / C V I .00636-13$

Roozegar, M.A., F.A. Jalilian, M.R. Havasian, J. Panahi and I. Pakzad, 2016. Antimicrobial effect of Pistacia atlantica leaf extract. Hypothesis, 12: 19-21. DOI: $10.6026 / 97320630012019$

Silva, J.O., K.N. Oliveira, K.J. Santos, M.M. Espirito-Santo and F.S. Neves et al., 2010. Effects of landscape structure and Eucalyptus genotype on the abundance and biological control of Glycaspis brimblecombei Moore (Hemiptera: Psyllidae). Neotrop. Entomol., 39: 91-96. DOI: 10.1590/S1519-566X2010000100012
Silva, J., W. Abebe, S.M. Sousa, V.G. Duarte and M.I. Machado et al., 2003. Analgesic and antiinflammatory effects of essential oils of eucalyptus. J. Ethnopharmacol., 89: 277-283. DOI: $10.1016 /$ j.jep.2003.09.007

Sulaiman, L.K., O.A. Oladele, I.A. Shittu, B.O. Emikpe and A.T. Oladokun et al., 2011. In-ovo evaluation of the antiviral activity of methanolic root-bark extract of the African Baobab (Adansonia digitata Lin). Afr. J. Biotechnol., 10: 4256-4258. DOI: $10.5897 / A J B 10.2225$

Taylor, J., C. Edbauer, A. Rey-Senelonge, J.F. Bouquet and E. Norton et al., 1990. Newcastle disease virus fusion protein expressed in a fowlpox virus recombinant confers protection in chickens. J. Virol., 64: 1441-1450. PMID: 2157037

Tohidi, M., M. Khayami, V. Nejati and H. Meftahizade, 2011. Evaluation of antibacterial activity and wound healing of Pistacia atlantica and Pistacia khinjuk. J. Med. Plants Res., 5: 4310-4314.

Wadood, A., N. Wadood and S. Shah, 1989. Effects of Acacia arabica and Caralluma edulis on blood glucose levels of normal and alloxan diabetic rabbits. J. Pak. Med. Associat., 39: 208-212. PMID: 2509753

Waihenya, R.K., M.M. Mtambo and G. Nkwengulila, 2002. Evaluation of the efficacy of the crude extract of Aloe secundiflora in chickens experimentally infected with Newcastle disease virus. J. Ethnopharmacol., 79: 299-304. DOI: $10.1016 / \mathrm{S} 0378-8741(01) 00370-1$

$\mathrm{Yu}$, L., Z. Wang, Y. Jiang, L. Chang and J. Kwang, 2001. Characterization of newly emerging Newcastle disease virus isolates from the People's Republic of China and Taiwan. J. Clin. Microbiol., 39: 3512-3519. PMID: 11574565 